\title{
Epigenetic regulation of inhibin $\alpha$-subunit gene in prostate cancer cell lines
}

\author{
P Balanathan, E M A Ball, H Wang, S E Harris'1, A N Shelling' and G P Risbridger \\ Centre for Urological Research, Monash Institute of Reproduction and Development, Monash University, Melbourne, Australia \\ ${ }^{1}$ Department of Obstetrics and Gynaecology, National Women's Hospital, Auckland, New Zealand \\ (Requests for offprints should be addressed to G P Risbridger, Centre for Urological Research, Monash Institute of Reproduction and Development, \\ Monash Medical Centre, 246 Clayton Road, Melbourne, Victoria 3168, Australia; Email: gail.risbridger@med.monash.edu.au)
}

\begin{abstract}
Inhibin was first identified as a gonad-derived regulator of pituitary $\mathrm{FSH}$; however, it has subsequently been shown to be a tumour suppressor in the gonad and adrenal glands. Whereas non-malignant regions of human primary prostate carcinomas express inhibin $\alpha$-subunit (INHA), malignant tissues lack INHA transcript and protein, which is consistent with epigenetic regulation of the inhibin $\alpha$-subunit gene (INHA) promoter. This study investigated whether methylation of the INHA promoter was responsible for inactivation of INHA transcription and translation in the prostate cancer cell lines, LNCaP, DU145 and PC3. Methylation of the promoter was revealed by bisulphite genomic sequencing and use of inhibitors of methylation and histone deacetylation resulted in reactivation of the INHA transcription and translation. Significant $(P<0.05)$ downregulation of a luciferase reporter gene downstream from a methylated INHA promoter compared with unmethylated INHA promoter occurred in vitro. The data demonstrate that promoter methylation is associated with downregulation of the INHA gene in prostate cancer cell lines, which is consistent with its tumour suppressive role. Therefore INHA has a significant role in prostate tumorigenesis.
\end{abstract}

Journal of Molecular Endocrinology (2004) 32, 55-67

\section{Introduction}

Inhibin, a member of the transforming growth factor $\beta$ superfamily, is a dimeric protein consisting of an $\alpha$ and a $\beta$ subunit. The $\alpha$-subunit is synthesised in precursor forms consisting of pre, pro, $\alpha_{\mathrm{N}}$ and $\alpha_{\mathrm{C}}$ components, whereas the $\beta$-subunit precursor form consists of only a pro and a $\beta$ region. The precursor $\alpha$ - and $\beta$-subunits link by disulphite bonds to form a $105 \mathrm{kDa}$ inhibin, which forms bioactive $30-31 \mathrm{kDa}$ inhibin $\alpha_{\mathrm{C}}-\beta$ after post-translational modification (Robertson et al. 1989). The $\beta$-subunits combine to form homo- or heterodimers called activin, whereas the $\alpha$-subunit does not dimerise. Inhibin was first identified by its ability for negative regulation of the secretion of follicle-stimulating hormone from the anterior pituitary. Since then it has been demonstrated that the inhibin $\alpha$-subunit (INHA) is tumour suppressive in INHA knockout mice. Both sexes of these knockout mice developed gonadal sex-cord tumours with very high penetrance. After gonadectomy of these mice, tumours of the adrenal glands occurred (Matzuk et al. 1992).

In contrast to the mouse model, the role of INHA in human cancers is equivocal. Postmenopausal women with granulosa or mucinous epithelial cell ovarian tumours show increased concentrations of INHA in serum and this is used as a valuable clinical marker of ovarian cancer (Healy et al. 1993, Robertson et al. 1999a,b). In contrast, positive immunostaining for INHA is associated with favourable prognosis in a proportion of patients with ovarian cancer (Ala-Fossi et al. 2000). There is also an apparent inconsistency between the observations in human adrenal tumour tissues and the role of INHA as an adrenal tumour suppressor in INHA-null mice. INHA immunoreactivity has been detected in adrenal cortical adenomas and carcinomas. Earlier studies showed positive staining for INHA in hyperplastic tissues and adrenocortical carcinomas (De Jong 
et al. 1990), which was later supported by data from larger studies in patients with adrenal cortical neoplasia (Arola et al. 1998, 2000, McCluggage et al. 1998, Pelkey et al. 1998, Fetsch et al. 1999, Munro et al. 1999). Similar to ovarian cancer, a subgroup of adrenal cortical carcinomas showed loss of INHA immunoreactivity (Munro et al. 1999). INHA immunoreactivity is used as a diagnostic marker that can differentiate adrenal cortical tumours from histologically similar tumours. The role of the INHA, if any, is yet to be determined in other cancers such as prostate cancer.

Mellor et al. (1998) reported that the INHA transcript (mRNA) and protein were not detected in malignant tissues from men with poorly differentiated prostate cancer. In contrast, the expression of INHA mRNA and protein was observed in tissues from adjacent non-malignant regions of the same patients or in men with benign prostatic hyperplasia (Mellor et al. 1998). Cytosine methylation of the INHA gene (INHA) promoter region was associated with loss of expression of INHA in malignant regions of prostate cancer specimens, and non-malignant regions adjacent to the cancer cells were less methylated compared with the malignant regions (Schmitt et al. 2002). Aberrant cytosine methylation at the $\mathrm{CpG}$ sites within the $5^{\prime}$ region of a gene has been associated with transcriptional repression and is a common mechanism in the silencing of tumour suppressor genes.

The human INHA is located on chromosome 2q33-36 and is composed of two exons separated by a $1.7 \mathrm{~kb}$ intron (Stewart et al. 1986, Debieve \& Thomas 2002). Consistent with the mouse, bovine and rat promoter regions, the human INHA promoter lacks an obvious TATA or CGAAT box and is not GC rich (Su \& Hsueh 1992). The INHA promoter contains several regulatory elements, including a cAMP response element, activator proteins 1 and 2, specificity protein 1 , steroidgenic factor 1, a potential Smad binding element, Rnf6 and GATA factors (Feng et al. 1998, Ito et al. 2000, Lopez et al. 2002, Schmitt et al. 2002).

In order to evaluate whether methylation is responsible for the inactivation of the expression of INHA in prostate cancer, we use androgendependent LNCaP and androgen-independent DU145 and PC3 prostate cancer cell lines that lack INHA expression (Batres et al. 1995, Furst et al. 1995, Ying et al. 1995), to determine the methylation status of the INHA promoter region.

\section{Materials and methods}

\section{Cell lines}

Human prostate tumour epithelial cell lines LNCaP, DU145 and PC3 and human hepatoma cell line HepG2 were obtained from American Type Culture Collection (Rockville, MD, USA). Cell lines were routinely cultured in Dulbecco's modified Eagle's medium (Gibco) with 10\% (v/v) heat-inactivated fetal calf serum (CSL Ltd, Parkville, Victoria, Australia) and antibiotics (100 IU/ml penicillin and $10 \mu \mathrm{g} / \mathrm{ml}$ streptomycin; CSL Ltd, Parkville, Victoria, Australia) in $75 \mathrm{ml}$ culture flasks (Falcon, BD Biosciences, Franklin Lakes, NJ, USA) at $37^{\circ} \mathrm{C}$ in a humidified atmosphere of $5 \% \mathrm{CO}_{2}$ in air. Cell lines were passaged every 4 days by trypsinisation.

\section{Bisulphite treatment of cells}

Trypsinised cells were recovered in $1 \times$ PBS and $1 \mu \mathrm{l}$ cell suspension was added to $9 \mu \mathrm{l}$ molten $1 \cdot 6 \%$ (w/v) low melting point agarose and placed into $1.5 \mathrm{ml}$ Eppendorf tubes. The agarose/cell beads were immediately solidified on ice. Controls containing all reagents, but no cells, were systematically included. Agarose/cell beads were set up in triplicate for each cell line.

Bisulphite treatment of DNA in agarose beads was according to the procedures of Olek et al. (1996) and Kerjean et al. (2001), with slight modification to suit the requirements of our experiments. Briefly, $200 \mu \mathrm{l}$ lysis solution $(0.5 \mathrm{M}$ EDTA, pH 8; $21 \mu \mathrm{l} 19 \mathrm{mg} / \mathrm{ml}$ proteinase $\mathrm{K}$ ) was deposited over the agarose beads containing the cells. The lysis solution was carefully removed using a syringe after overnight incubation at $50{ }^{\circ} \mathrm{C}$. The beads were then overlaid with $60 \mu \mathrm{l}$ freshly prepared $0.3 \mathrm{M} \mathrm{NaOH}$ for $30 \mathrm{~min}$ at room temperature in order to denature the DNA. Aliquots $(170 \mu \mathrm{l})$ of bisulphite solution $(2.5 \mathrm{M}$ sodium metabisulphite (BDH Laboratory Supplies, Poole, Dorset, UK) and $125 \mathrm{mM}$ hydroquinone (BDH Laboratory Supplies) pH 5) were directly added to each reaction tube. The reaction mixtures were incubated for $16 \mathrm{~h}$ at $50{ }^{\circ} \mathrm{C}$ in the dark. The bisulphite solutions containing the beads were then heated to $80{ }^{\circ} \mathrm{C}$ for $10 \mathrm{~min}$ to melt the agarose. The modified DNA was purified using Wizard DNA Glean-Up System (Promega Cooperation, Madison, WI, USA) according to the manufacturer's 
instructions, and eluted into $50 \mu \mathrm{l}$ water. The elution mixture was then spun for $2 \mathrm{~min}$ at maximum speed to pellet any resin that might have escaped from the DNA Clean-Up System. The supernatant was transferred to new tubes to complete the modifications. Then a $0 \cdot 1 \times$ volume of $3 \mathrm{M} \mathrm{NaOH}$ was added to the DNA and incubated for $15 \mathrm{~min}$ at $37^{\circ} \mathrm{C}$, followed by addition of $22 \mu \mathrm{l}$ of $6 \mathrm{M} \mathrm{NH}_{4} \mathrm{OAc}, \mathrm{pH}$. The bisulphitereacted DNA was precipitated for $30 \mathrm{~min}$ at $-20{ }^{\circ} \mathrm{C}$ in $250 \mu \mathrm{l} 100 \%$ (v/v) cold ethanol, washed with $75 \%(\mathrm{v} / \mathrm{v})$ ethanol and resuspended in $50 \mu \mathrm{l}$ water.

\section{Methylation analysis}

Seven CpG sites in a 135 bp region of the INHA promoter were the focus of the previous methylation study in primary carcinomas (Schmitt et al. 2002). After further analysis of the untranslated region (UTR) of the INHA promoter, the region of study was expanded to include an additional two $\mathrm{CpG}$ sites. The methylation status of the INHA promoter in the three cell lines was determined by analysing the degree of methylation in nine $\mathrm{CpG}$ sites in a $500 \mathrm{bp} \mathrm{5}$ ' UTR from the start of translation. The new region of study, which included the previously studied CpG sites and two additional CpG sites, was amplified from the bisulphite-treated DNA using nested primers. The primers were designed for the coding strand using sequence published by Schmitt et al. (2002) from regions that lacked $\mathrm{CpG}$ dinucleotides (Fig. 1). The nested PCR amplifications contained $1 \times$ PCR buffer (inclusive of $\mathrm{MgCl}_{2}$ ), $2 \mathrm{mM}$ dNTPs, $10 \mu \mathrm{M}$ primers (Inha me 1, Inha me 2 for round 1 and Inha me 3, Inha me 4 for round 2; Table 1), $2.5 \mathrm{U}$ Taq polymerase and $3 \mu \mathrm{l}$ bisulphite-treated DNA in a total volume of $75 \mu \mathrm{l}$. After completion of the first round of amplification, $3 \mu \mathrm{l}$ were withdrawn and used as template for the second round of amplification. Conditions for the first round of amplification were 1 cycle of $94{ }^{\circ} \mathrm{C}$ for $2 \mathrm{~min} ; 5$ cycles of $94{ }^{\circ} \mathrm{C}$ for $1 \mathrm{~min}, 52{ }^{\circ} \mathrm{C}$ for $2 \mathrm{~min}, 72{ }^{\circ} \mathrm{C}$ for $3 \mathrm{~min} ; 25$ cycles of $94{ }^{\circ} \mathrm{C}$ for $0.5 \mathrm{~min}, 52{ }^{\circ} \mathrm{C}$ for $2 \mathrm{~min}, 72^{\circ} \mathrm{C}$ for $1.5 \mathrm{~min}$ and 1 cycle of $72^{\circ} \mathrm{C}$ for $6 \mathrm{~min}$. Conditions for the second round of amplification were 1 cycle of $94{ }^{\circ} \mathrm{C}$ for $2 \mathrm{~min}, 25$ cycles of $94{ }^{\circ} \mathrm{C}$ for $0.5 \mathrm{~min}$, $52{ }^{\circ} \mathrm{C}$ for $2 \mathrm{~min}, 72^{\circ} \mathrm{C}$ for $1.5 \mathrm{~min}$ and 1 cycle of $72{ }^{\circ} \mathrm{C}$ for $6 \mathrm{~min}$. Each bisulphite-treated DNA was set up for PCR in triplicate.
The PCR products were gel purified and the recovered products were analysed by digestion with BstN1 to assess if the bisulphite treatment of the DNA was complete. Bisulphite treatment converts unmethylated cytosines $(\mathrm{C})$ to thymidine $(\mathrm{T})$, leaving methylated cytosines unconverted. The recognition site for Bst $\mathcal{N} 1$ is $\mathrm{CG} / \mathrm{XGG}$, where $\mathrm{X}$ is either A or T. Thus successful conversion of the $\mathrm{C}$ to $\mathrm{T}$ will change the BstN1 recognition to TT/XGG and the enzyme will fail to digest the product. The amplified region contains five Bst N1 recognition sites (Fig. 1). Only PCR products that were not cleaved by this enzyme were cloned into pGEM-T Easy vector (Promega) and transformed into DH5 $\alpha$-competent cells. Ten colonies from each ligated PCR product were miniprepped and sequenced with primer, Inha me 4 . Therefore, a total of 90 colonies per cell line were used to determine the methylation status of the INHA promoter in each of the respective cell lines.

\section{Treatment of LNCaP, DU145 and PC3 with DNA methylation inhibitor and histone deacetylase inhibitor}

The prostate cancer cell lines were seeded at a density of $5 \times 10^{5}$ cells $/ 100 \mathrm{~mm}$ tissue culture dish. The cells were allowed to attach to the dishes for $24 \mathrm{~h}$ and exposed to different concentrations of the DNA methylation inhibitor, 5-aza-2'-deoxycytidine (5-aza-dC) and the histone deacetylase inhibitor, trichostatin A (TSA), both individually and combined. For individual treatment, 5-aza-dC was added every $48 \mathrm{~h}$ in aqueous solution at final concentrations of 100,50 and $10 \mu \mathrm{M}$ for a total of $96 \mathrm{~h}$ and TSA dissolved in DMSO was added $24 \mathrm{~h}$ before harvest at final concentrations of 300 and $200 \mathrm{ng} / \mathrm{ml}$. For combined treatment, cells were exposed to $100 \mu \mathrm{M}$ 5-aza-dC for $96 \mathrm{~h}$ and to $300 \mathrm{ng} / \mathrm{ml}$ TSA for the last $24 \mathrm{~h}$ period.

\section{Total RNA extraction from cell lines}

Trizol (2 ml) (Invitrogen) was added to each $100 \mathrm{~mm}$ tissue culture dish to lyse the cells. The lysates were transferred into $1.5 \mathrm{ml}$ Eppendorf tubes and $200 \mu \mathrm{l}$ chloroform was added for every $1 \mathrm{ml}$ of Trizol. This was mixed thoroughly by shaking and incubated at room temperature for 3 min. The Eppendorf tubes were centrifuged at $4{ }^{\circ} \mathrm{C}$ for $15 \mathrm{~min}$ at maximum speed. The upper 


\begin{abstract}
${ }^{-646}$ TGgtCtAAgt AtAgAgCAgG CAgGACCACC TGCCCCCGgC CCTAGCCCCG Inh a me 1

${ }^{-596}$ GTtCTAGCCC CGgTTCCAGC CCTGCCCCAA GGGCTGGCCG GCCAGCAgCT

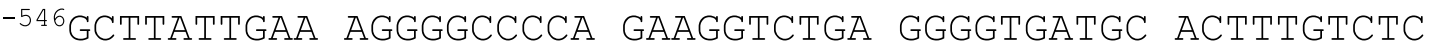
${ }^{-496}$ CCTGACAAAT AACACTTTCT GgGgCTGGCC GGCTACAGCT CCCAGGCTCC ${ }^{-446}$ TGTCCCACCT GATGTCACCT CTGGATGTGT CTGTGTGTGT GTGTGTGTGA

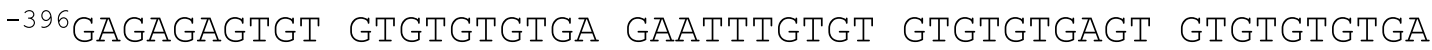

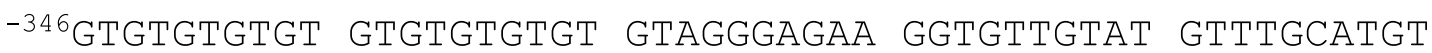
${ }^{-296}$ GTGAgtCAgG TCGCTTGAgG CGAAATCCTT CCCAgCCCCT CCCCCACATC

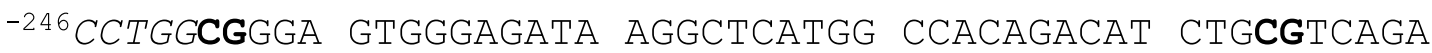

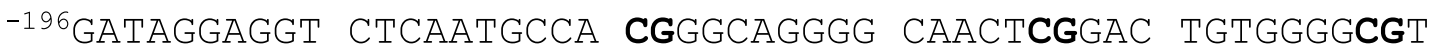

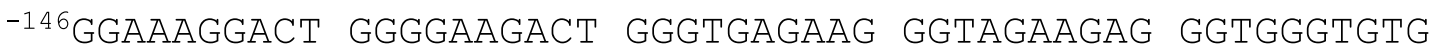
${ }^{-96}$ GgAtgggaAg GgGAgAgtgG AAAggcCCTG GgCAgACCCT GGCAgAAggG ${ }^{-46}$ GCACggGgCA GgGtgtgagt TCCCCACtAg CAgGgCCAGG TGAGCT ${ }^{-1}$ ${ }^{1}$ Atggtgctgc ACCTACtgCt cttcttgctg ctgAcccCAC AgggtgggcA Inh a me 4



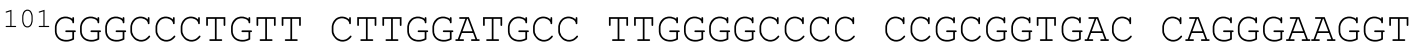
${ }^{151}$ GgGgACCCTG GAgTCAgGCG GCTGCCCCGA AgACATGCCC TGgGgGgCtT
\end{abstract} ${ }^{201} \mathrm{CACACACAGG}$

Inh a me 2

Figure 1 Partial sequence of the INHA. The sequence above shows the region used to design primers to amplify a 500 bp promoter region from the bisulphite-treated DNA. The primer sequences shown in Table 1 have all $\mathrm{C}$ converted to T. The primers were designed to avoid $\mathrm{CpG}$ sites, which are highlighted in bold. The numbers show the positions of the nucleotides in the INHA with respect to $A T G=1$. The $B s t N /$ recognition sites are shown in italics.

layer was then transferred into fresh $1.5 \mathrm{ml}$ Eppendorf tubes and $500 \mu \mathrm{l}$ isopropanol was added for every $1 \mathrm{ml}$ Trizol, to precipitate the RNA. This was centrifuged at $4{ }^{\circ} \mathrm{C}$ for $10 \mathrm{~min}$ at maximum speed. All isopropanol was removed and the pellet washed with $75 \%(\mathrm{v} / \mathrm{v})$ ethanol. After removal 
Table 1 Primers for bisulphite experiment and RT-PCR

\begin{tabular}{|c|c|c|}
\hline & Primer name & Primer sequence \\
\hline \multicolumn{3}{|l|}{ Target } \\
\hline \multirow[t]{4}{*}{ Inhibin $\alpha$-promoter } & Inh a me 1 & TGGTTTAAGTATAGAGTAGGTAGGATTATT \\
\hline & Inh a me 2 & ССТАТАTATAAAACCСCСАAАACATATCT \\
\hline & Inh a me 3 & TTTTAGAAGGTTTGAGGGGTGATGTATTTTG \\
\hline & Inh a me 4 & CAACAAAAAAAACAATAAATACAACACCAT \\
\hline \multirow{3}{*}{ Inhibin $\alpha$} & Inh a ORF F2 & CCTGTTCTTGGATGCCTTG \\
\hline & Inh a ORF R2 & AGCTGGGCTGAAGTCACCT \\
\hline & Inh a ORF F3 & TGAGGACAAGTCAGCTGCCAGA \\
\hline$\beta_{2}$-microglublin & b2mg F & CCGTGTGAACCATGTGACTT \\
\hline$\beta_{2}$-miroglubin & b2mg R & CAAACATGGAGACAGCACTC \\
\hline
\end{tabular}

of the ethanol, the pellet was air-dried for a few minutes and resuspended in $30 \mu \mathrm{l}$ diethyl pyrocarbonate (DEPG) water.

Total RNA $(0.5 \mu \mathrm{g} / \mu \mathrm{l})$ was treated with DNAfree kit (Ambion, Austin, TX, USA) according to the manufacturer's instructions, with slight modifications. Briefly, $0 \cdot 1 \times$ of $10 \times$ DNase I buffer and $1 \mu \mathrm{l}$ DNase I (2 U) were added to the total RNA. This was mixed gently and incubated at $37^{\circ} \mathrm{C}$ for $30 \mathrm{~min}$. Then $1 \mu \mathrm{l}$ DNase I was added to the total RNA and further incubated for $30 \mathrm{~min}$ at $37^{\circ} \mathrm{C}$. The DNase Inactivation Reagent was resuspended by vortexing and a $0 \cdot 1 \times$ volume was added to the RNA. The tube was incubated for $2 \mathrm{~min}$ at room temperature and then centrifuged at $10000 \boldsymbol{g}$ for $1 \mathrm{~min}$ to pellet the DNase Inactivation Reagent. The total RNA was removed to fresh tubes, care being taken to avoid the resin.

\section{RT-PCR analysis}

DNA-free-treated total RNA $(2 \cdot 5 \mu \mathrm{g})$ was added to $1 \mu \mathrm{l}$ Random Hexamer $(50 \mu \mathrm{M}$; Roche, Mannheim, Germany) and $1 \mu \mathrm{l} 10 \mathrm{mM}$ dNTP mix, and the volume was made up to $12 \mu \mathrm{l}$ with $\mathrm{DEPC}$ water. The reaction was incubated at $65^{\circ} \mathrm{C}$ for $5 \mathrm{~min}$ and chilled on ice after a quick spin. Then $4 \mu \mathrm{l}$ $5 \times$ first-strand synthesis buffer (Invitrogen), $2 \mu \mathrm{l}$ $0 \cdot 1 \mathrm{M}$ dTT (Invitrogen) and $1 \mu \mathrm{l}$ RNase inhibitor (40 $\mathrm{U} / \mu \mathrm{l})$ (Promega) were added to the tubes and incubated for $2 \mathrm{~min}$ at $42{ }^{\circ} \mathrm{C}$. Superscript II $(1 \mu \mathrm{l})$ (Invitrogen) was added to positive reverse transcription tubes $(+\mathrm{RT})$ and $1 \mu \mathrm{LEPG}$ water added to control tubes $(-\mathrm{RT})$. Tubes were then incubated at $42{ }^{\circ} \mathrm{C}$ for $1 \mathrm{~h}$. The enzymes were inactivated at $70{ }^{\circ} \mathrm{C}$ for $15 \mathrm{~min}$.
The resulting cDNA $(1 \mu \mathrm{l})$ was used in each PCR. Intron-spanning primers were designed using the Primer3 Output program. Primer sequences for the housekeeping gene, $\beta_{2}$-microglobulin $\left(\beta_{2} m g\right)$ and INHA are given in Table 1 . The PCR program for $\beta_{2} m g$ was $94{ }^{\circ} \mathrm{C}$ for $5 \mathrm{~min} ; 30$ cycles of $30 \mathrm{~s}$ at $94{ }^{\circ} \mathrm{C}, 30 \mathrm{~s}$ at $58{ }^{\circ} \mathrm{C}$ and $30 \mathrm{~s}$ at $72{ }^{\circ} \mathrm{C} ; 72^{\circ} \mathrm{C}$ for $7 \mathrm{~min} . \beta_{2} m g$ was used to test the quality of $\mathrm{cDNA}$.

The amplification profile for INHA expression involved preincubation at $94{ }^{\circ} \mathrm{C}$ for $5 \mathrm{~min}$, denaturation at $94{ }^{\circ} \mathrm{C}$ for $1 \mathrm{~min}$, and primer annealing at a temperature decreasing from $65^{\circ} \mathrm{C}$ to $56^{\circ} \mathrm{C}$ by 1 min each cycle for 10 cycles, then $55{ }^{\circ} \mathrm{C}$ for $1 \mathrm{~min}$ for an additional 30 cycles and extension at $72{ }^{\circ} \mathrm{C}$ for $1 \mathrm{~min}$ for all cycles. All cDNA amplification for INHA expression was achieved using a ThermoHybrid PCR machine (Ashford, Middlesex, UK). All PCR products were run on $1 \%(\mathrm{w} / \mathrm{v})$ agarose gels.

\section{Southern blotting}

INHA expression in the cell lines was analysed by Southern blotting. The gels were transferred onto Hybond XL membrane (Amersham Pharmacia Biotech) using $0.4 \mathrm{M} \mathrm{NaOH}$ as the transfer medium. The membranes were washed in $2 \times \mathrm{SSC}$ and incubated in hybridisation buffer $[50 \times$ Denhardt's (2\% (w/v) BSA, 2\% (w/v) Ficoll, 2\% (w/v) polyvinylpyrrolidone); $0.5 \mathrm{M} \mathrm{NaH}{ }_{2} \mathrm{PO}_{4} \mathrm{pH} 6.5$; $20 \times \mathrm{SSC} ; 10 \%(\mathrm{w} / \mathrm{v}) \mathrm{SDS}$; deionised formamide; herring sperm $(10 \mathrm{mg} / \mathrm{ml})]$ at $42{ }^{\circ} \mathrm{C}$ for $1 \mathrm{~h}$. Internal primer, INHA open reading frame $\mathrm{F} 3$ (Inha ORF F3; Table 1) was labelled with $\gamma^{32} \mathrm{P}$-ATP using trinucleotide kinase and added to the hybridisation buffer with the membranes. The 
membranes were probed overnight and washed twice with $2 \times \mathrm{SSC} / 0 \cdot 1 \% \quad(\mathrm{w} / \mathrm{v}) \quad \mathrm{SDS}$ and $0 \cdot 5 \times \mathrm{SSC} / 0 \cdot 1 \%(\mathrm{w} / \mathrm{v}) \mathrm{SDS}$. The membranes were sealed in plastic sleeves and exposed to XOMAT film (Scientific Imaging System, Rochester, NY, USA) and developed after $4 \mathrm{~h}$.

\section{Reporter constructs}

A reporter construct consisting of the INHA promoter driving a luciferase gene (pGL3enhancer) was created ( $\mathrm{S}$ Harris \& A Shelling, unpublished observations). The promoter region was subcloned into pGL3-basic backbone (Promega). These aliquots of the constructs were treated individually to have one of three states of methylation: normal, unmethylated and methylated. To maintain the initial characteristics of the INHA promoter, DH5 $\alpha$-competent cells were transformed with the normal construct to retain any methylation of the $\mathrm{CpG}$ sites already present on the promoter. SCS110-competent cells (Stratagene Cloning System, La Jolla, CA, USA) do not express the DNA methyltransferase enzymes that are responsible for DNA methylation. These cells were transformed with the INHA promoter construct to ensure that the replicating DNA was not methylated. The methylated INHA promoter construct was created by treating the INHA promoter region with SssI methlylase to methylate the CpG sites fully, followed by ligation of the methylated promoter into the pGL3-basic vector.

\section{Transient transfections}

The mouse adrenal cell line (kindly provided by Dr Paul Farnworth, Prince Henry's Institute of Medical Research, Melbourne, Australia) was plated in 24-well plates, grown to a density of 70-80\% and transfected using Superfect (Qiagen Pty Ltd, Clifton Hill, Vic, Australia). Transfection was performed in $n=4$ wells to help control for variation in cell number and culture conditions. Cells were cotransfected with $1.8 \mu \mathrm{g}$ specific plasmids at optimised concentrations plus $50 \mathrm{ng}$ Renilla luciferase plasmid pRL-TK (as a control for transfection efficiency). The transfection reagent-DNA complexes were incubated with cells for $3 \mathrm{~h}$ before the media was replaced with normal growth media. The cell lysates were prepared after $48 \mathrm{~h}$.

\section{Luciferase assays}

Luciferase and renilla assays were performed using the Dual-Luciferase reporter assay kit (Promega Corporation) as instructed by the supplier. Briefly, after $48 \mathrm{~h}$ the cells were washed with PBS and lysed in $150 \mu \mathrm{l} /$ well of Passive lysis buffer. The cells were incubated in the lysis buffer for $30 \mathrm{~min}$ on a rocker at room temperature and the cell lysates collected. Then $20 \mu$ cell lysate from each transfection well were added to 96-well luminescent solid assay plates (Corning, Acton, MA, USA). Luciferase assay reagent $(100 \mu \mathrm{l})$ was added and firefly luciferase measured on a LumniCount 96-well plate reader (Packard, Meriden, CT, USA). After a luciferase reading, $100 \mu \mathrm{l}$ Stop \& Glo reagent was added to each well and renilla luciferase was measured. The luciferase activities are represented as relative activities (firefly luciferase activity divided by renilla luciferase activity).

\section{Immunohistochemical staining for the INHA protein}

An INHA antibody, monoclonal Rl antibody (kindly provided by Dr Nigel Groome, Oxford Brookes University, Oxford, UK) was used to determine expression of the INHA in the prostate cancer cell lines.

LNGaP, DU145 and PG3 cell lines were seeded in eight-well Lab-Tek II chamber slides with covers (Nalge Nunc International, Naperville, IL, USA). The slides were coated with fibronectin before use to ensure that the cells attached to the slides. Each cell line was set up in duplicate slides. After $24 \mathrm{~h}$ of growth, six wells per cell line were treated with $100 \mu \mathrm{M} 5$-aza-dC and four wells per cell line were kept as untreated controls for 6 days. After a PBS wash, the cells were fixed on the slides using 70\% (v/v) ethanol for $2 \mathrm{~min}$. The chambers were taken off before the immunostaining procedure.

R1 immunostaining was performed by DAKO Autostainer (DAKO, Carpinteria, California, USA). After incubation with $0.03 \% \mathrm{H}_{2} \mathrm{O}_{2}$ (DAKO) for $5 \mathrm{~min}$ to block the endogenous peroxidase, the cells were incubated for 60 min with R1 antibody diluted as $7 \cdot 5 \mu \mathrm{g} / \mathrm{ml}$. The antibody was detected by incubation with Envision polymer-antimousehorseradish peroxidase (DAKO) for $15 \mathrm{~min}$ and visualised by reaction with diaminobenzidine (DAKO) for $5 \mathrm{~min}$. Concentration-matched mouse IgG1 was used as negative control. 
Estimation of the percentage of cells stained for R1 was performed using stereological methods, as described previously (McPherson et al. 2001). Briefly, for each cell line, one well for untreated and five wells for demethylated cell lines were examined under $20 \times$ magnification using an Olympus microscope (BX50F4). The images were captured by a PULNiX TMC-6 video camera coupled to an IBM computer and projected using a Screen Machine II fast multimedia video adaptor (FAST electronic, GmbH, Germany). The computer program CASTGRID Version $2 \cdot 1 \cdot 4$ (Olympus, Denmark) was used to generate an unbiased counting frame. The slides were mapped to define well boundaries and sampled at predetermined intervals along $\mathrm{X}$ and $\mathrm{Y}$ axes using one counting frame. Positively and negatively stained cells were counted and a total of 300-400 cells per well were obtained. The results were expressed as percentage of positive cells of the total number of cells counted.

\section{Statistical analysis}

The methylation levels of individual $\mathrm{CpG}$ sites were expressed as percentage of 5-methyl-cytosine among the entire population (methylated and unmethylated). A single $\mathrm{C}$ at the corresponding $\mathrm{CpG}$ site was considered to represent 100\% methylation, a single $\mathrm{T}$ as no methylation and overlapping $\mathrm{C}$ and $\mathrm{T}$ as partial methylation. Data are given as means \pm S.E.M. The $t$-test was used for statistical analyses and to determine statistical significance, $* *(P<0 \cdot 05)$.

\section{Results}

\section{Methylation status of the INHA promoter in prostate cancer cell lines}

The prostate cancer cell lines LNCaP, DU145 and PC3 did not express the INHA transcript by RT-PCR as previously demonstrated (data not shown). Methylation of the INHA promoter was revealed in these cell lines by bisulphite genomic sequencing. The primers used to identify the regions of methylation were designed to avoid $\mathrm{CpG}$ sites, because the methylation status of any of the CpG sites of interest was not known in these cell lines. Nine $\mathrm{CpG}$ sites are located in a 500 bp region $5^{\prime}$ from the start of translation in the INHA promoter region (Fig. 2a). Sequencing of the bisulphite-treated DNA revealed that methylation was not confined to a specific $\mathrm{CpG}$ site, but included all nine $\mathrm{CpG}$ sites, spanning the region of interest. The methylation pattern observed ranged from densely to sparsely methylated profiles, with CpG sites 0-3 being undermethylated in DU145 and PC3 cell lines compared with the LNCaP cell line (Fig. 2b).

\section{5-aza-dC and TSA reactivate INHA expression in prostate cancer cell lines}

To evaluate the role of methylation in the inactivation of the INHA promoter in the cell lines, a DNA methyltransferase inhibitor, 5-aza-dC and a histone deacetylase inhibitor, TSA, were used. Treatment of the DU145 and PC3 cell lines with 100, 50 and $10 \mu \mathrm{M}$ 5-aza-dC induced expression of INHA mRNA (Fig. 3). The level of expression of mRNA in the LNCaP cell line was much lower than that in the DU145 and PC3 cell lines. Treatment with 300 and $200 \mathrm{ng} / \mathrm{ml}$ TSA did induce expression of INHA mRNA, but at very low levels. A combination of 5-aza-dC and TSA did not change the pattern of expression of mRNA compared with the 5-aza-dC or TSA treatments alone.

\section{A methylated INHA promoter represses transcription in a transient system}

To determine whether methylation of the INHA promoter is sufficient to repress the expression of INHA and if an unmethylated INHA promoter retains its transcriptional activity, we transfected the mouse adrenal cell (AC) line with INHA promoter constructs with various methylation states. The AC cell line expresses high levels of free INHA (Farnworth et al. 2001) and there is a high sequence homology $(70 \%)$ between the mouse and human INHA promoter region (Su \& Hsueh 1992, Schmitt et al. 2002). The INHA promoter region consisting of the segment required for optimal activity and the $\mathrm{CpG}$ sites of interest was cloned into pGL3-basic. Transient transfection of the AG cell line with a methylated INHA promoter-pGL3basic construct resulted in a decrease in the relative luciferase reporter gene activity compared with the normal and unmethylated INHA promoter-pGL3basic constructs (Fig. 4). The relative luciferase 


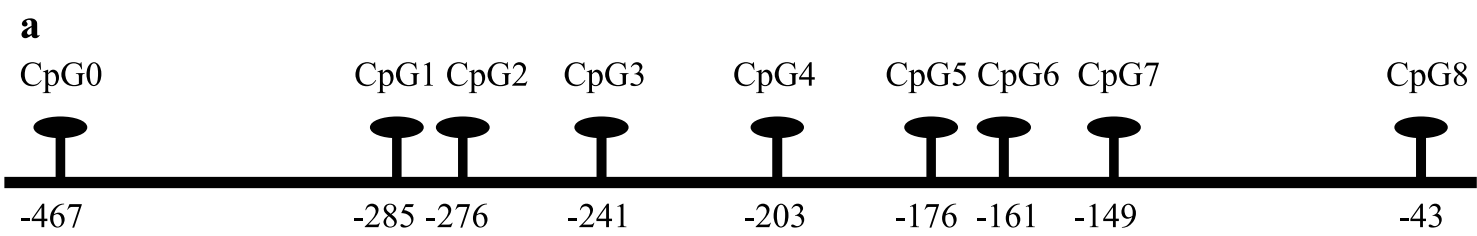

b
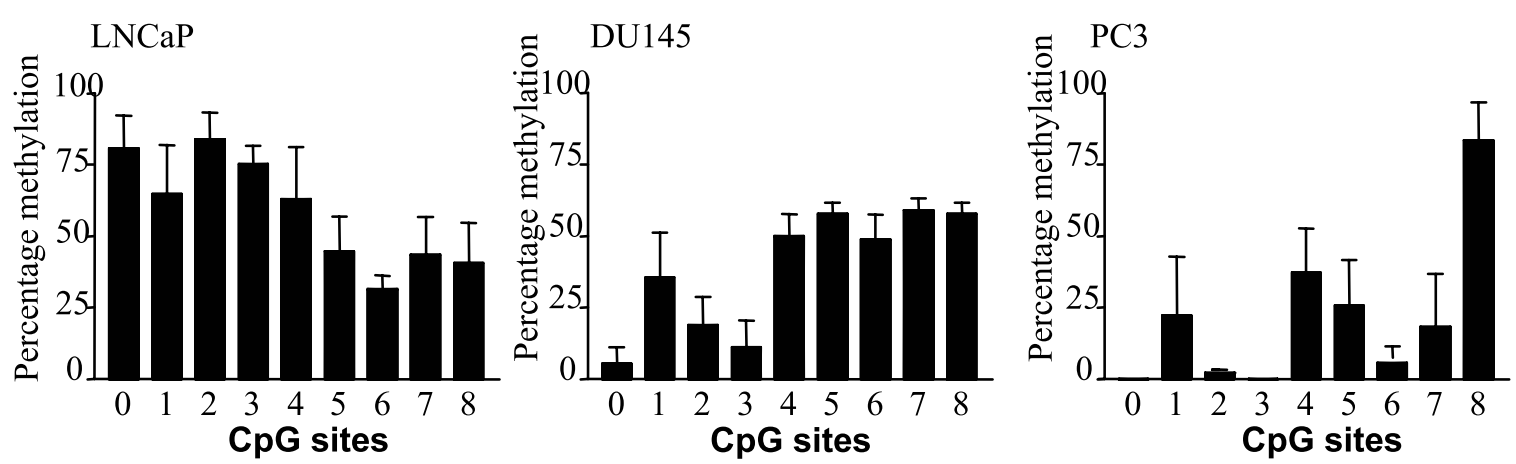

Figure 2 The INHA promoter is methylated in prostate cancer cell lines. (a) Map of the CpG sites in the INHA promoter in the 500 bp $5^{\prime}$ UTR from the start of translation. (b) Mean percentage methylation of each of the nine CpG sites in the INHA promoter region studied, in prostate cancer cells. After bisulphite treatment, the INHA promoter was PCR-amplified and the product cloned. Each of the experimental steps was performed in triplicate. Methylation status was determined by sequence analysis of 90 clones for each cell line. The percentage methylation shown in (b) was determined for each of the CpG sites identified in (a).

activity showed a significant increase $(P<0 \cdot 05)$ when the $\mathrm{AC}$ cell line was transfected with an unmethylated INHA promoter-pGL3-basic construct as compared with transfection with an methylated INHA promoter-pGL3-basic construct. The normal INHA promoter-pGL3-basic construct showed a non-significant increase in the relative luciferase activity compared with the methylated INHA promoter-pGL3-basic construct.

\section{Demethylation of the INHA promoter reactivates INHA protein expression}

To establish whether or not methylation is responsible for the inactivation of INHA transcription and subsequently its translation, immunostainings of demethylated and untreated cell lines were carried out using the monoclonal Rl antibody. The percentage of positively stained cells in demethylated LNCaP and DU145 cell lines was low compared with the demethylated PC3 cell line (Table 2). An example of the positive staining for INHA expression in the demethylated cell lines is shown in Fig. 5.

\section{Discussion}

Similar to malignant regions of primary human prostate carcinomas, the cell lines LNCaP, DU145 and PC3 fail to express INHA transcript and protein. These cell lines also demonstrate different degrees of androgen sensitivity, which makes them useful models with which to study different stages of prostate cancer. The previously studied methylation status of primary prostate cancer focused on seven CpG sites (CpG1-CpG7) in a 135 bp region in the UTR of the INHA promoter. Further analysis of a $500 \mathrm{bp} \mathrm{5'}$ UTR from the start of translation identified two more CpG sites (CpG0 and CpG8) and transcription factor binding sites that might be important in the downstream processing of the INHA. The present data extend our previous observations on human prostate specimens. Schmitt et al. (2002), and uses human prostate cell lines to study the implications of changes in the INHA promoter in terms of degree of gene silencing, the effects of induced demethylation on gene re-expression at mRNA and protein levels, and the effects of gene silencing at a functional level. 


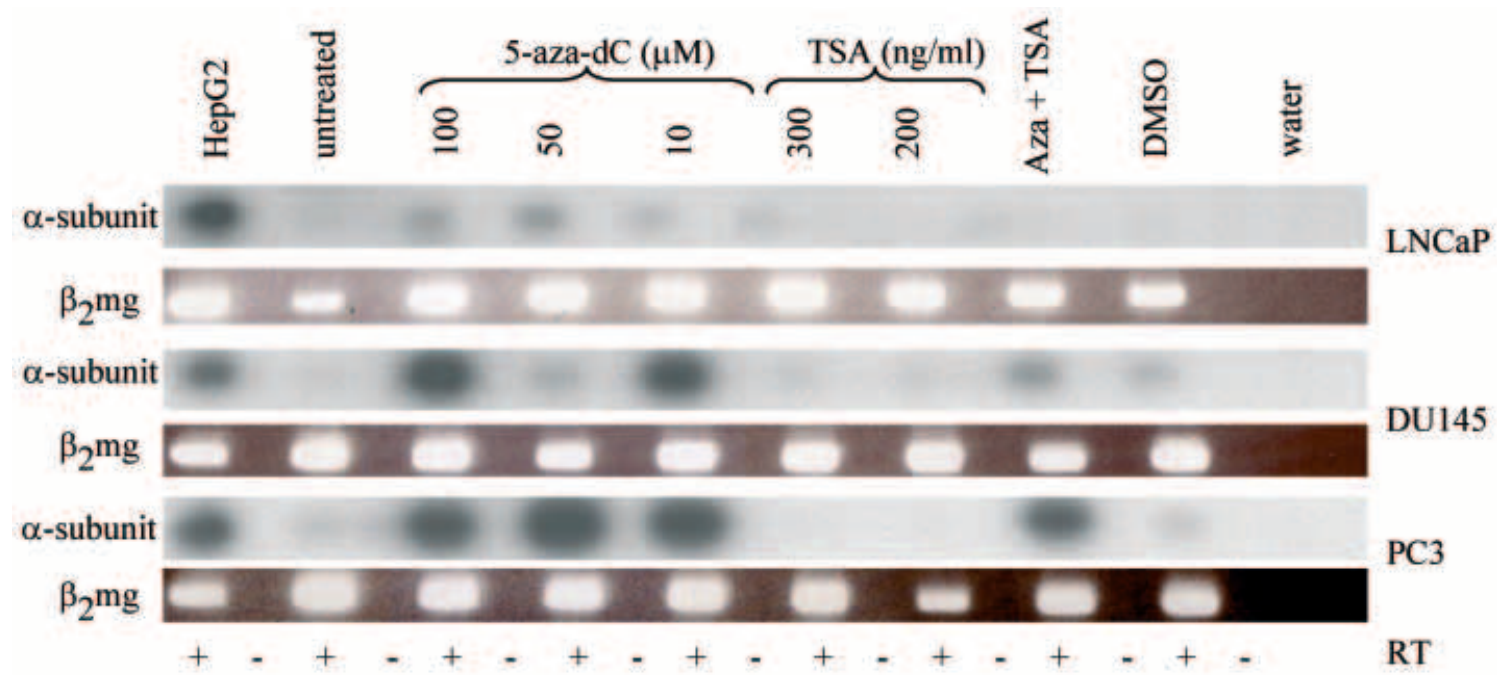

Figure 3 Demethylation, and to a lesser extent deacetylation, reactivates expression of INHA in prostate cancer cell lines. The cells were treated with 5-aza-dC and TSA to determine if methylation or acetylation, or both, was responsible for the absence of INHA expression. RT-PCR followed by Southern blotting were used to analyse the pattern of expression of INHA after treatment. A negative cDNA control (-RT) was run in every alternate lane from the left to confirm the integrity of the cDNA strand. cDNA from HepG2 cell line was used as the positive control for INHA expression. $\beta_{2}$-Microglobulin $\left(\beta_{2} m g\right)$ was used as loading control. TSA was dissolved in DMSO vehicle.

The results of our study demonstrate that the INHA promoter is extensively methylated in LNCaP, DU145 and PC3 prostate cancer cell lines, which were confirmed to lack expression of INHA mRNA. The use of cell lines provides a relatively pure population of cells for such methylation studies and prevents contamination from normal or surrounding tumour cells that may present a major concern because different methylation patterns may exist in this heterogeneous population of primary tumour cells. There is a difference in the degree of methylation at specific CpG sites in the primary prostate carcinoma and that in the current cell line study; nevertheless, together these studies unequivocally demonstrate that the INHA promoter is methylated in prostate cancer. The primary prostate carcinomas showed methylation of CpG sites $1-4$ and 7 and some methylation of $\mathrm{CpG}$ site 6, whereas $\mathrm{CpG}$ site 5 remained unmethylated in prostate carcinoma (Schmitt et al. 2002). The various patterns of methylation may be the result of random de novo methylation, the presence of competition between DNA methyltransferase (DNMT) and transcription factors or the presence of contaminating cell populations. As cells divide, the presence and absence of various factors such as transcriptional activators, repressors and enzymes such as polymerases have key roles at the molecular level. De novo methylation of the DNA by DNMT maintains the CpG sites in a methylated state as the DNA replicates and cells divide. Methyl CpG binding protein preferentially binds to methylated cytosines and in turn participates in complexes that contain active histone deacetylases. Thus the presence of these protein complexes within the promoter region blocks the binding of specific transcription factors and polymerases to their sites (Baylin \& Herman 2000). Alternatively, the presence of transcription factors and polymerases at their binding region within the promoter prevents the binding of DNMT to the CpG sites and inhibits methylation at these sites.

There is extensive methylation of the INHA promoter in all the three cell lines studied, but the degree of methylation between the cell lines differs. The androgen-dependent LNCaP cell line is highly methylated compared with the androgenindependent DU145 and PC3 cell lines, but whether the sensitivity to androgens contributes to the degree of methylation remains to be explained. The expression of DNMT mRNA has been shown to be increased in cancer cells compared with samples of benign prostatic hyperplasia $(\mathrm{Li}$ et al. 


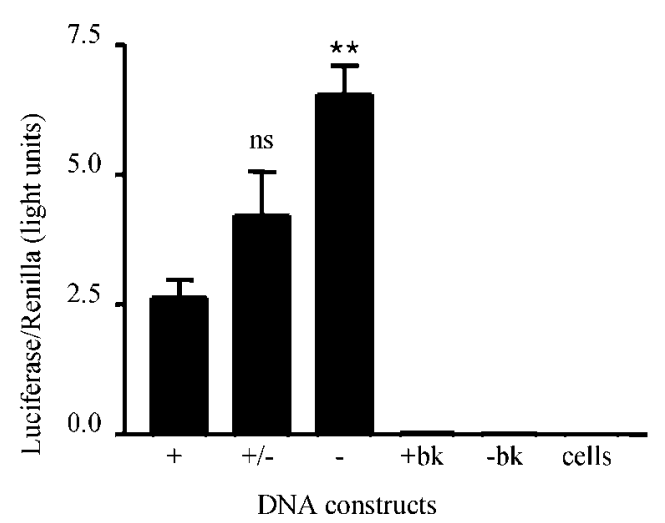

Figure 4 Methylation status regulates the activity of the INHA promoter. The mouse adrenal cell line (AC) was transiently transfected with three forms of INHA promoters in PGL-basic vectors: +, methylated, in which the insert was treated with Sss 1 methylase; +/- normal untreated; -, unmethylated, in which the construct was replicated in SCS110 E. coli competent cells lacking DNA methyltransferase enzymes. The $\mathrm{pRL}-\mathrm{TK}$ renilla luciferase plasmid was cotransfected to adjust for transfection efficiency. bk, cells transfected with empty vector. ${ }^{* \star} P<0 \cdot 05$, significant difference between methylated INHA-pGL3 basic and unmethylated INHA-pGL3-basic; ns, no significant difference between methylated INHA-pGL3 basic and normal INHA-pGL3-basic.

Table 2 Percentage of cells staining positively for $\mathrm{RI}$ in untreated and demethylated cell lines. Values are mean \pm S.D.

\begin{tabular}{|c|c|c|}
\hline & Untreated & Demethylated \\
\hline Cell lines & & \\
\hline $\begin{array}{l}\text { LNCaP } \\
\text { DU145 }\end{array}$ & $\begin{array}{l}0 \\
0\end{array}$ & $\begin{array}{l}0.09 \pm 0.15 \\
0.36+0.22\end{array}$ \\
\hline PC3 & 0 & $8.17 \pm 2.04$ \\
\hline
\end{tabular}

2000). Recent evidence showed that increased DNMT activity is an early event in carcinogenesis (Belinsky et al. 1996, Laird 1997). Our results are consistent with this concept, as LNCaP and PC3 cell lines can respectively represent the early androgen-dependent and late androgenindependent stages of carcinogenesis.

In the prostate cancer cell lines analysed in our study, expression of INHA mRNA was correlated well with the methylation status of those cell lines after treatment with the demethylation agent, 5-aza-dC and a histone deacetylase inhibitor, TSA. Induction of mRNA expression by treatment of the LNCaP, DU145 and PC3 cell lines with 5-aza-dC and TSA demonstrates the presence of all necessary transcription factors for successful transcription of the INHA in these cell lines. The results demonstrate that the level of expression achieved by the cell lines is dependent on the degree of methylation within the promoter region. A reciprocal relationship between the degree of methylation and re-expression of the INHA was seen after treatment with 5-aza-dC. PC3 cell lines that were the least methylated were easily demethylated and expressed high levels of INHA mRNA, whereas LNCaP cell lines that were the most highly methylated showed less expression. The pattern of methylation also reflects on the level of expression of protein. Immunostaining of the demethylated cell lines showed expression of the INHA protein, whereas no expression was evident in the untreated cell lines. The percentage of positively stained cells in demethylated LNCaP and DU145 cell lines was low compared with that in demethylated PC3 cell lines. In vitro methylation and demethylation of the INHA-promoter-driven luciferase reporter construct respectively showed distinct repression and expression of the luciferase reporter activity.

Methylation of $\mathrm{CpG}$ sites within the regulatory regions of tumour suppressor genes is a common aberration in human cancers and is often associated with gene silencing. In the current study we have shown evidence that methylation is responsible for the silencing of the INHA gene in prostate cancer cell lines. Other genes that have been shown to be selectively methylated in their $5^{\prime}$ promoter regions in many prostate cancers include EDNRD (Nelson et al. 1997), encoding the endothelin B receptor, CD44 (Lou et al. 1999), a cell adhesion molecule encoding a gene with metastasis suppressor activity in rat prostate cancer, oestrogen receptor $\alpha$ and $\beta$ (Sasaki et al. 2002), androgen receptor (Sasaki et al. 2002) and glutathione S-transferase P1 (Singal et al. 2001). Although methylation studies are important in determining the cause of gene silencing, they have their drawbacks in terms of functional studies. Induced demethylation reactivates several promoters in the model of study, therefore any functional changes cannot be associated with the re-expression of a particular gene.

The data presented in this study demonstrate that methylation of the INHA promoter in the prostate is the primary reason for inactivation of 


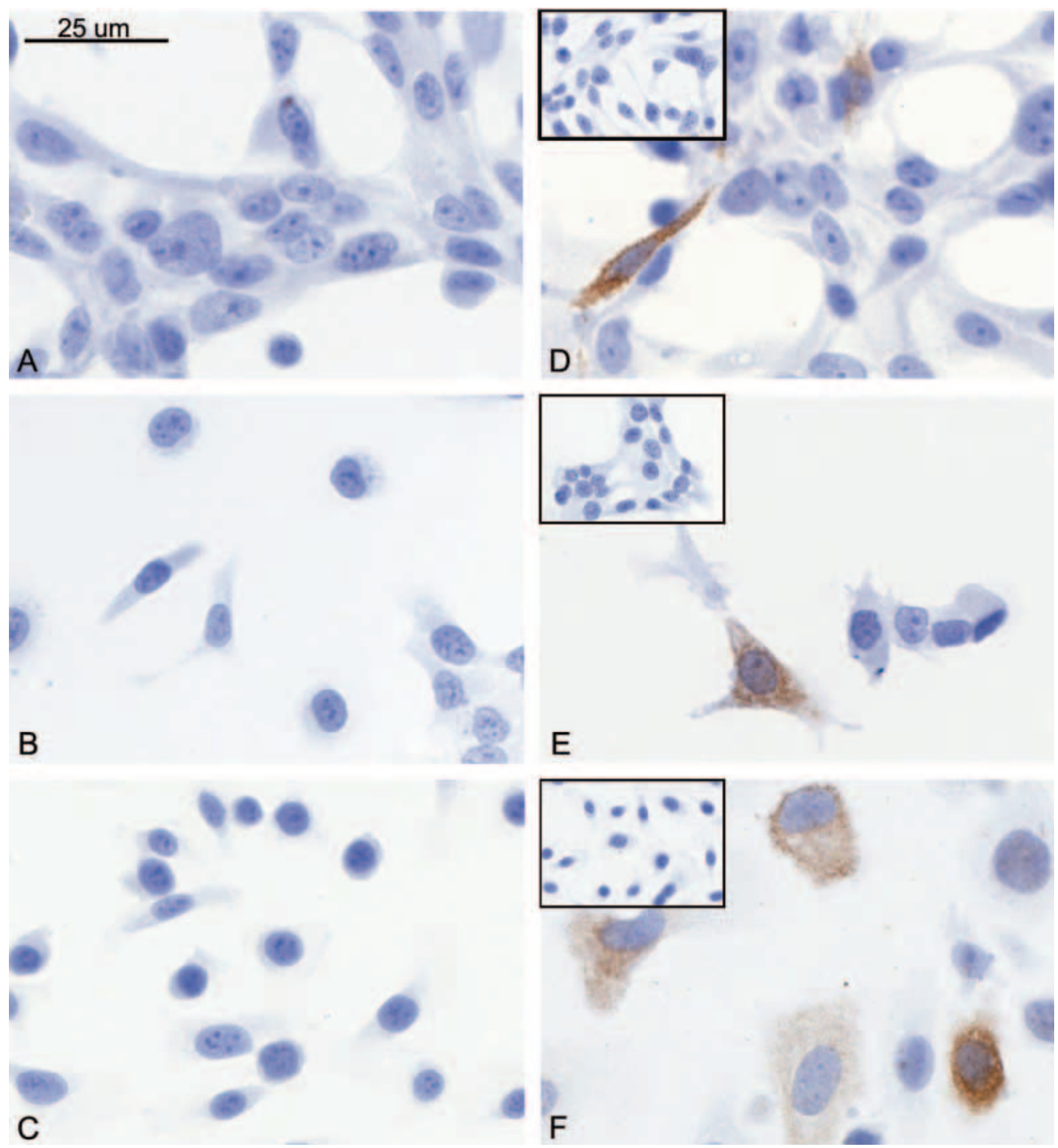

Figure 5 Demethylation induces expression of INHA protein in the prostate cancer cell lines. The immunoreactivity of INHA protein in demethylated cell lines was detected using monoclonal R1 antibody. The cells were treated with 100 MM 5-aza-dC in chambered slides. The untreated LNCaP, DU145 and PC3 cell lines (A-C respectively) displayed no immunoreactivity. Specific staining of INHA protein was observed in demethylated LNCaP, DU145 and PC3 cell lines (D-F respectively). No specific immunoreactivity was recorded in the control cells incubated with mouse IgG1 (inserts). Scale bar represents $25 \mu \mathrm{m}$. 
INHA expression in prostate cancer cell lines. In this study, repression of the gene activity by methylation had a dominant role over TSAsensitive histone deacetylase activity. In conclusion, the INHA is well characterised for epigenetically mediated aberrant transcriptional silencing in prostate cancer cell lines and therefore this study adds further evidence to support the hypothesis that INHA has an important role in prostate tumorigenesis as a putative tumour suppressor. So far, methylation of the INHA promoter is evident in both primary and cultured prostate tumours, but whether or not methylation of the INHA promoter is a cause or a consequence of malignancy remains to be determined and functional studies of the INHA may provide insights into the development of prostate cancer. The present study demonstrated increased methylation of the INHA promoter in androgen-dependent cells compared with that in androgen-independent cells. Similar studies can be used as a diagnostic method to detect early forms of prostate cancer and, if diagnosis is made early, 5-aza-dC or its analogues can be used as therapeutic measures to reactivate the expression of those genes of which the inactivation is responsible for prostate cancer development.

\section{Acknowledgements}

We thank Dr Jacqueline Schmitt for her contributions, Dr Paul Farnworth for kindly providing the AC cell lines and Dr Nigel Groome for the R1 antibody. The work was supported by National Health \& Medical Research Council programme grant.

\section{References}

Ala-Fossi SL, Aine R, Punnonen R \& Maenpaa J 2000 Is potential to produce inhibins related to prognosis in ovarian granulosa cell tumors? European Fournal of Gynecological Oncology 21 187-189.

Arola J, Liu J, Heikkila P, Voutilainen R \& Kahri A 1998 Expression of inhibin alpha in the human adrenal gland and adrenocortical tumors. Endocrine Research 24 865-867.

Arola J, Liu J, Heikkila P, Ilvesmaki V, Salmenkivi K, Voutilainen R \& Kahri A 2000 Expression of inhibin alpha in adrenocortical tumours reflects the hormonal status of the neoplasm. Fournal of Endocrinology 165 223-229.

Batres Y, Zhang Z \& Ying SY 1995 Expression of activins and activin receptor messenger RNAs in LNCaP cells, a human prostatic adenocarcinoma cell line. International Fournal of Oncology 6 $1185-1188$.
Baylin SB \& Herman JG 2000 DNA hypermethylation in tumorigenesis: epigenetics joins genetics. Trends in Genetics $\mathbf{1 6}$ 168-174.

Belinsky SA, Nikula KJ, Baylin SB \& Issa JP 1996 Increased cytosine DNA-methyltransferase activity is target-cell-specific and an early event in lung cancer. PNAS 93 4045-4050.

Debieve F \& Thomas K 2002 Control of the human inhibin alpha chain promoter in cytotrophoblast cells differentiating into syncytium. Molecular Human Reproduction 8 262-270.

De Jong FH, Grootenhuis AJ, Steenbergen J, van Sluijs FJ, Foekens JA, ten Kate FJ, Oosterhuis JW, Lamberts SW \& Klijn JG 1990 Inhibin immunoreactivity in gonadal and non-gonadal tumors. Fournal of Steroid Biochemistry and Molecular Biology 37 863-866.

Farnworth PG, Harrison CA, Leembruggen P, Chan KL, Stanton PG, Ooi GT, Rahman NA, Huhtaniemi IT, Findlay JK \& Robertson DM 2001 Inhibin binding sites and proteins in pituitary, gonadal, adrenal and bone cells. Molecular and Cellular Endocrinology 180 63-71.

Feng ZM, Wu AZ \& Chen CL 1998 Testicular GATA-1 factor up-regulates the promoter activity of rat inhibin alpha-subunit gene in MA-10 Leydig tumor cells. Molecular Endocrinology 12 378-390.

Fetsch PA, Powers CN, Zakowski MF \& Abati A 1999 Anti-alpha-inhibin: marker of choice for the consistent distinction between adrenocortical carcinoma and renal cell carcinoma in fine-needle aspiration. Cancer Cytopathology 87 168-172.

Furst BA, Zhang Z \& Ying SY 1995 Expression of activins and activin receptors in human prostatic carcinoma cell line DU145. International Fournal of Oncology 7 239-243.

Healy DL, Burger HG, Mamers P, Jobling T, Bangah M, Quinn M, Grant P, Day AJ, Rome R \& Campbell JJ 1993 Elevated serum inhibin concentrations in postmenopausal women with ovarian tumors. New England Fournal of Medicine 329 1539-1542.

Ito M, Park Y, Weck J, Mayo KE \& Jameson JL 2000 Synergistic activation of the inhibin alpha-promoter by steroidogenic factor-1 and cyclic adenosine $3^{\prime}, 5^{\prime}$-monophosphate. Molecular Endocrinology 14 66-81.

Kerjean A, Vieillefond A, Thiounn N, Sibony M, Jeanpierre M \& Jouannet P 2001 Bisulfite genomic sequencing of microdissected cells. Nucleic Acids Research 29 E106-6.

Laird PW 1997 Oncogenic mechanisms mediated by DNA methylation. Molecular Medicine Today 3 223-229.

Li LC, Chui R, Nakajima K, Oh BR, Au HC \& Dahiya R 2000 Frequent methylation of estrogen receptor in prostate cancer: correlation with tumor progression. Cancer Research 60 702-706.

Lopez P, Vidal F, Martin L, Lopez-Fernandez LA, Rual JF, Rosen RB, Cuzin F \& Rassoulzadegan M 2002 Gene control in germinal differentiation: RNF6, a transcription regulatory protein in the mouse sertoli cell. Molecular and Cellular Biology 22 3488-3496.

Lou W, Krill D, Dhir R, Becich MJ, Dong JT, Frierson HFJ, Isaacs WB, Isaacs JT \& Gao AC 1999 Methylation of the CD44 metastasis suppressor gene in human prostate cancer. Cancer Research 59 2329-2331.

McCluggage WG, Burton J, Maxwell P \& Sloan JM 1998 Immunohistochemical staining of normal, hyperplastic, and neoplastic adrenal cortex with a monoclonal antibody against alpha inhibin. Fournal of Clinical Pathology 51 114-116.

McPherson SJ, Wang H, Jones ME, Pedersen J, Iismaa TP, Wreford N, Simpson ER \& Risbridger GP 2001 Elevated androgens and prolactin in aromatase-deficient mice cause enlargement, but not malignancy, of the prostate gland. Endocrinology 142 2458-2467.

Matzuk MM, Finegold MJ, Su JG, Hsueh AJ \& Bradley A 1992 Alpha-inhibin is a tumour-suppressor gene with gonadal specificity in mice. Nature $360313-319$.

Mellor SL, Richards MG, Pedersen JS, Robertson DM \& Risbridger GP 1998 Loss of the expression and localization of inhibin 
alpha-subunit in high grade prostate cancer. Fournal of Clinical Endocrinology and Metabolism 83 969-975.

Munro LM, Kennedy A \& McNicol AM 1999 The expression of inhibin/activin subunits in the human adrenal cortex and its tumours. Fournal of Endocrinology $161341-347$.

Nelson J, Lee W, Nguyen S, Jarrard D, Brooks J, Magnuson S, Opgenorth T, Nelson W \& Bova G 1997 Methylation of the 5' $\mathrm{CpG}$ island of the endothelin $\mathrm{B}$ receptor gene is common in human prostate cancer. Cancer Research 59 2329-2331.

Olek A, Oswald J \& Walter J 1996 A modified and improved method for bisulphite based cytosine methylation analysis. Nucleic Acids Research 24 5064-5066.

Pelkey TJ, Frierson HF Jr, Mills SE \& Stoler MH 1998 The alpha subunit of inhibin in adrenal cortical neoplasia. Modern Pathology $11516-524$.

Robertson DM, Giacometti M, Foulds LM, Lahnstein J, Goss NH, Hearn MT \& de Kretser DM 1989 Isolation of inhibin alpha-subunit precursor proteins from bovine follicular fluid. Endocrinology 125 2141-2149.

Robertson DM, Cahir N, Burger HG, Mamers P \& Groome N $1999 a$ Inhibin forms in serum from postmenopausal women with ovarian cancers. Clinical Endocrinology 50 381-386.

Robertson D, Cahir N, Burger H, Mamers P, McCloud P, Pettersson K \& McGuckin M $1999 b$ Combined inhibin and CA125 assays in the detection of ovarian cancer. Clinical Chemistry 45 651-658.
Sasaki M, Tanaka Y, Perinchery G, Dharia A, Kotcherguina I, Fujimoto S \& Dahiya R 2002 Methylation and inactivation of estrogen, progesterone, and androgen receptors in prostate cancer. Fournal of the National Cancer Institute 94 384-390.

Schmitt JF, Millar DS, Pedersen JS, Clark SL, Venter DJ, Frydenberg M, Molloy PL \& Risbridger GP 2002 Hypermethylation of the inhibin alpha-subunit gene in prostate carcinoma. Molecular Endocrinology 16 213-220.

Singal R, van Wert J \& Bashambu M 2001 Cytosine methylation represses glutathione S-transferase P1 (GSTP1) gene expression in human prostate cancer cells. Cancer Research 61 4820-4826.

Stewart AG, Milborrow HM, Ring JM, Crowther CE \& Forage RG 1986 Human inhibin genes. Genomic characterisation and sequencing. Federation of European Biochemical Societies Letters 206 329-334

Su JG \& Hsueh AJ 1992 Characterization of mouse inhibin alpha gene and its promoter. Biochemical and Biophysical Research Communications 186 293-300.

Ying SY, Zhang Z \& Xing W 1995 Expression of activin and activin receptors in PC3 human prostatic cancer cells. International fournal of Oncology 6 601-606.

Received in final form 29 September 2003 Accepted 28 October 2003 